\title{
Notes on the discovery and ecology of the invasive armoured catfish Pterygoplichthys disjunctivus (Weber, 1991) and the exotic cichlid Amphilophus trimaculatus (Gunther, 1867) from Southern West Bengal, India
}

\author{
Priyankar Chakraborty ${ }^{1, *}$, Suktara Chakraborti ${ }^{1}$, Prasun Mukherjee ${ }^{2}$, Kranti Yardi ${ }^{1}$, Subhankar Das ${ }^{3}$
}

${ }^{1}$ Bharati Vidyapeeth Institute of Environment Education and Research, (BVIEER),

Bharati Vidyapeeth (Deemed to be University),

Pune, India-411043

${ }^{2}$ School of Water Resources Engineering, Jadavpur University, Kolkata, India-700031.

${ }^{3}$ Zoology Department, Vidyasagar College, Kolkata, India-700006

"priyankarchakraborty1991@gmail.com

Received: 24 July 2019 / Accepted: 19 November 2019

\begin{abstract}
This paper documents the first occurrence of an intergrade form of the highly invasive, South American armoured suckermouth catfish Pterygoplichthys disjunctivus (Weber, 1991) from the brackish waters of the Sundarban Tiger Reserve, West Bengal, India and the exotic Central American cichlid Amphilophus trimaculatus (Gunther, 1867) from Southern Bengal, India. Another species of cichlid Etroplus suratensis (Bloch, 1790) native to Southern India is also recorded for the wild for the first time from West Bengal. Notes on the possible threats due to invasion, sources of introduction, extent of spread and management of these and other invasive species are discussed in the paper.
\end{abstract}

Key words: exotic species, naturalization, hybridisation, ornamental fish, uncontrolled spread, aquarium trade.

\section{Introduction}

The spread of invasive species coupled with the extinction of native species has resulted in what is termed as biotic homogenisation and is a worldwide phenomenon (Rahel, 2002). Native ichthyofauna is often consigned a minor status as community members or even extirpated, thereby resulting in entire food webs comprising of introduced species (Pullan \& Smith, 1987; Gozlan et al., 2010). The ornamental fish trade is a crucial pathway for the occurrence of fish fauna from disparate regions (Raghavan et al., 2013; Bijukumar et al., 2015). Leidy and Moyle (1998) defined by product introductions as a phenomenon that results from aquaculture operations, pet fish released by aquarist, and fish carried in the ballast water of ships. South American catfishes of the family Loriicaridae are popular throughout the world as pets especially for their role as a cleaner fish to remove algae. These fishes have been successful in invading most parts of the world (Krishnakumar et al., 2009; Hossain et al., 2008; Nico et al., 2009; Liang et al., 2005). Similarly, fishes of the order Cichliformes have successfully invaded ecosystems worldwide (Courtnay, 1997; Nico et al., 2019). Tilapias (Oreochromis spp.) are a celebrated example of spread and invasion by cichlids across the world (Gozlan et al., 2010).

India has about 1000 species of fishes in freshwater ecosystems among them 26 species of fishes are exotic and or invasive and they were introduced for aquaculture purposes and mosquito control (Froese \& Pauly (eds.), 2019). 
The impact of these introduced species of fishes on the native ichthyofauna is very scantily studied. Hence a lack of information to precede the management of these invasive species. Our study reviews the discovery of a specimen of Pterygoplichthys disjunctivus (Weber, 1991) from the protected brackish area of the Sundarban tiger reserve, India as well as the discovery of two specimens of Amphilophus trimaculatus (Gunther, 1867) from a wet market in Southern West Bengal and examines the potential effect of these species on the local aquatic ecosystems as well as commenting on the approaches of management.

\section{Materials and methods}

The fishes were collected and the live fish were euthanized using clove oil mixed in ethanol and water. Following that, they were transferred to $10 \%$ formalin for fixation and then moved to $70 \%$ ethanol for preservation. The specimens were deposited to Bharati Vidyapeeth Institute of Environment Education and Research (BVIEER), Pune, India. Registration numbers are $P$. disjunctivus BVIEER/ FC-002, A. trimaculatus BVIEER/FC 003-004). Measurements and counts of bilaterally symmetrical features were taken from the left side of the body, whenever possible. Measurements were taken using a digital calliper to the nearest $0.1 \mathrm{~mm}$. Counts were done using a stereozoom transmitted light microscope (EISCO). Identification followed using standard literature (Ambruster, 2001; Page \& Robins, 2006; Říčan et al., 2016) and FishBase (Froese \& Pauly (eds.), 2019).

\section{Results and discussion}

The intergrade form of the Pterygoplichthys disjunctivus specimen was collected from the buffer zone of the Sundarban tiger reserve $\left(22^{\circ} 10^{\prime} 28.1^{\prime \prime} \mathrm{N} / 088^{\circ} 49^{\prime} 17.8^{\prime \prime} \mathrm{E}\right)$ where

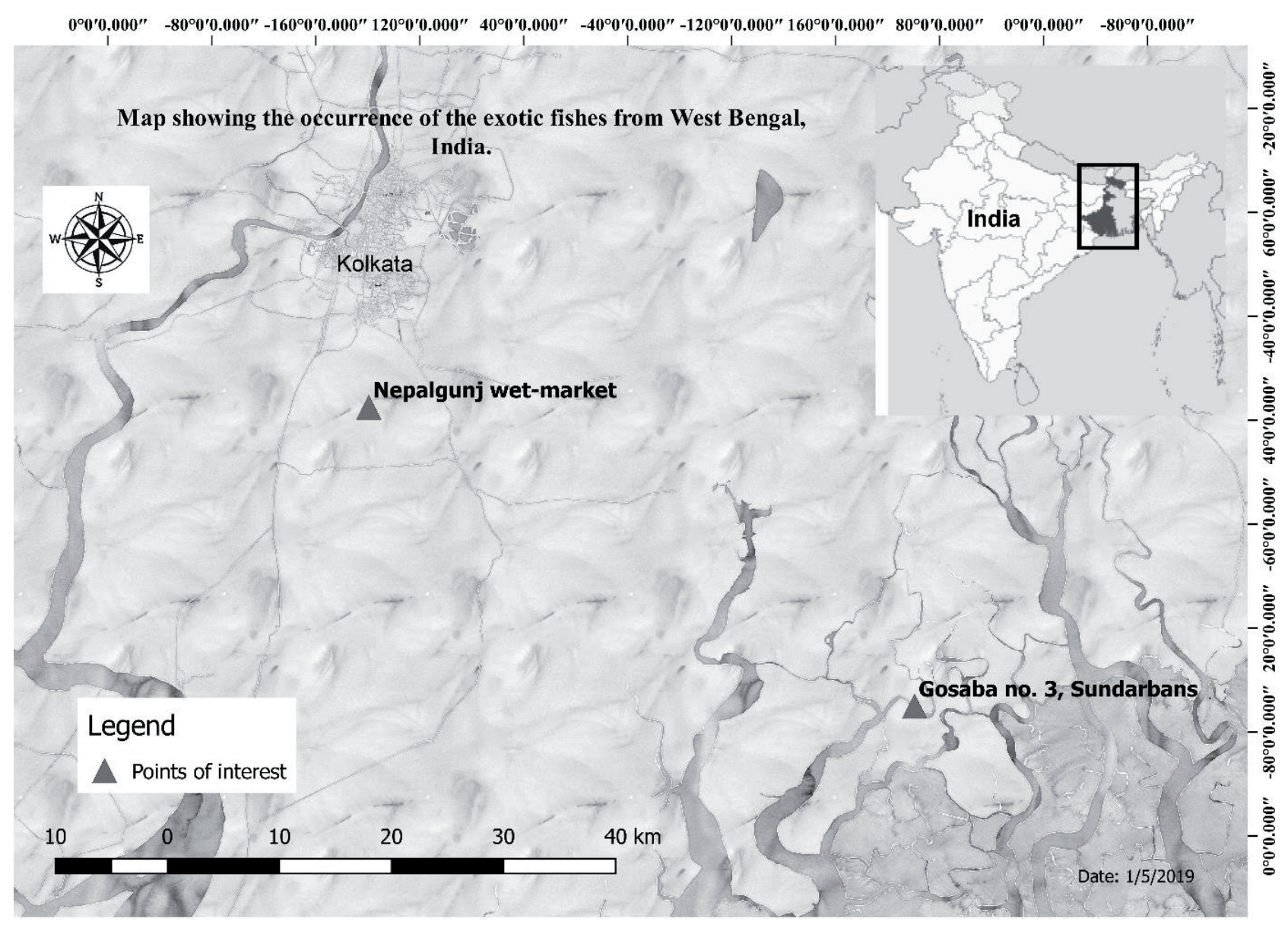

Figure 1. Map showing the occurrence of Pterygoplichthys disjunctivus (Weber, 1991) from Sundarbans, India and Amphilophus trimaculatus (Gunther, 1867) from Nepalgunj wet market, India (Inset, the location of West Bengal on the eastern part of India) 


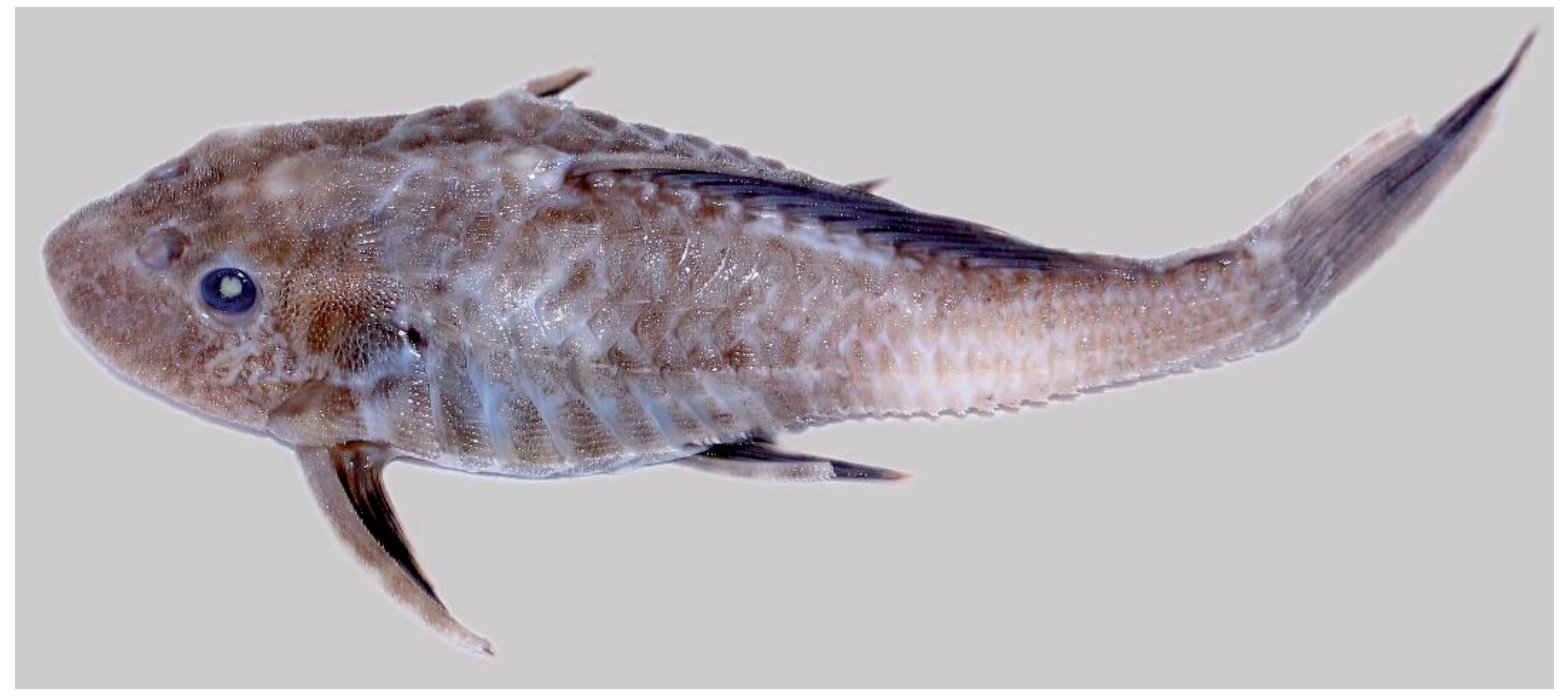

Figure 2. An intergrade morphological form of the species Pterygoplichthys disjunctivus (Weber, 1991) BVIEER/FC 002, SL $81.98 \mathrm{~mm}$

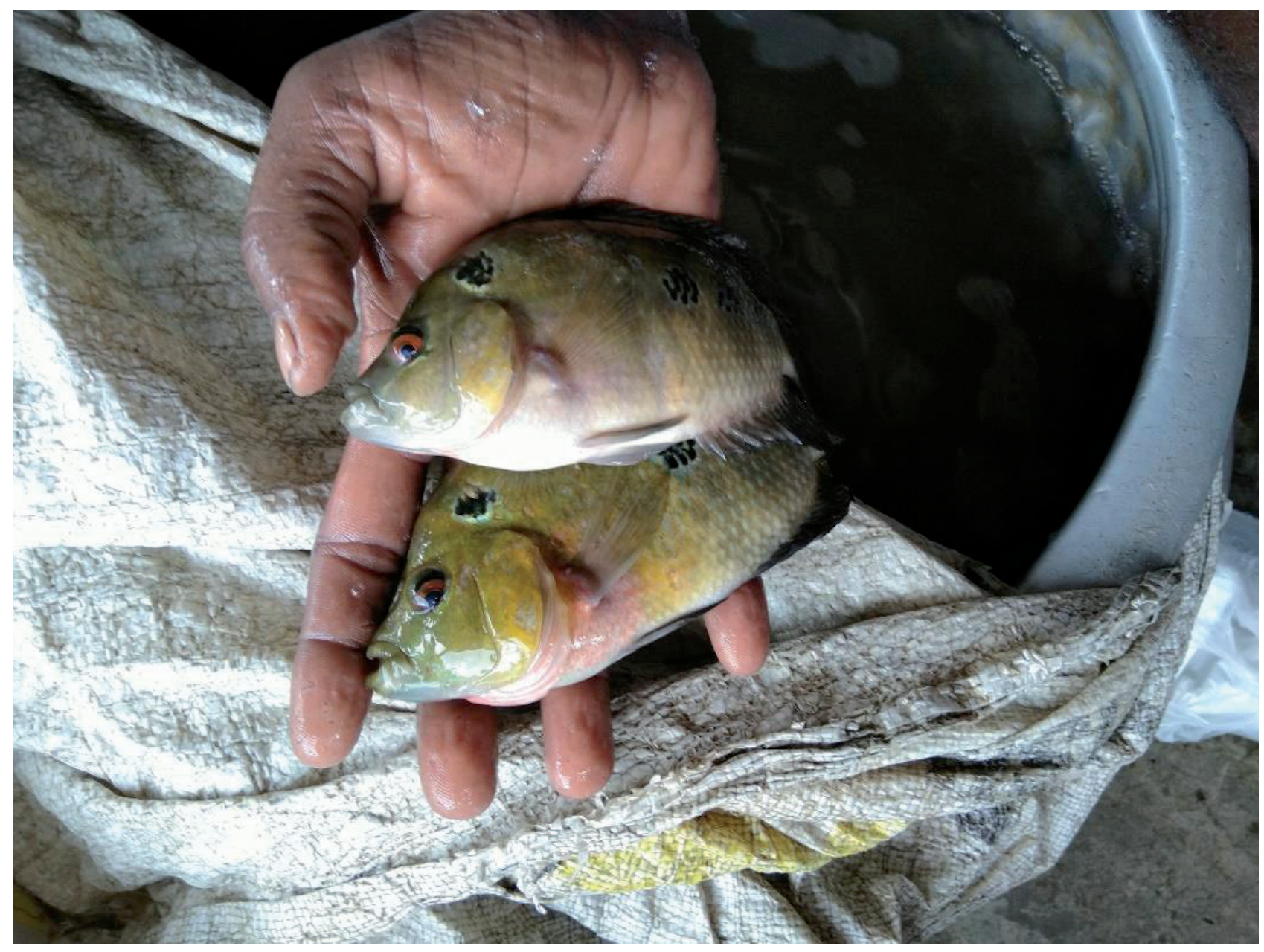

Figure 3. Amphilophus trimaculatus (Gunther, 1867) being sold at Nepalgunj wet-market. BVIEER//FC 003-004, SL $121.43-131.09 \mathrm{~mm}$ 
an artisanal fishing boat had caught it in their fishing net 'Benthi Jaal' a form of bag net. The two individuals of A. trimaculatus were collected from the Nepalgunj fish market $\left(22^{\circ} 24^{\prime} 48.9^{\prime \prime} \mathrm{N} / 088^{\circ} 20^{\prime} 60^{\prime \prime}\right.$ E) in Southern West Bengal (Fig. 1). The E. suratensis was recorded and photographed by the fifth author from the catch of a fisher who was selling his catch at a local village market in Sundarbans. The fisher had caught this fish in his 'Khyapla Jaal', cast net. No specimen was collected or deposited nor were any GPS points recorded. The examination of the specimens based on Morphometric, meristic characteristics (Table 1) and patterns and colouration revealed that the armoured catfish is most likely an intergrade morphological form of the species Pterygoplichthys disjunctivus (Weber, 1991) locally known in the pet trade as 'crocodile fish' and

Table 1. The morphometric and meristic measurements of the two recorded species of fishes

\begin{tabular}{|l|c|c|}
\hline \multicolumn{1}{|c|}{ Character } & $\begin{array}{c}\text { Pterygoplichthys } \\
\text { disjunctivus } \\
\text { (Weber, 1991) } \\
\text { n=1 }\end{array}$ & $\begin{array}{c}\text { Amphilophus } \\
\text { trimaculatus } \\
\text { (Gunther, 1867) } \\
\mathbf{n = 2}\end{array}$ \\
\hline Total length & 112.81 & $153.55-165.04$ \\
\hline Standard length & 81.98 & $121.43-131.09$ \\
\hline Head length & 19.69 & $46.53-48.42$ \\
\hline Body depth & 19.43 & $57.23-58.49$ \\
\hline Greatest width of head & 22.3 & $25.88-27.2$ \\
\hline Greatest height of head & 17.07 & $43.73-46.6$ \\
\hline Snout length & 13.71 & $15.7-16.5$ \\
\hline Eye diameter & 5.76 & $11.72-13.75$ \\
\hline Interorbital width & 12.78 & $15.76-16.39$ \\
\hline $\begin{array}{l}\text { Length of caudal } \\
\text { peduncle }\end{array}$ & 27.3 & $15.88-16.16$ \\
\hline $\begin{array}{l}\text { Height of caudal } \\
\text { peduncle }\end{array}$ & 7.4 & $18.45-20.41$ \\
\hline Pre-dorsal length & 31.76 & $50.51-54$ \\
\hline Post-dorsal length & 50.57 & $91.26-92.03$ \\
\hline Caudal length & 36.65 & $34.97-36$ \\
\hline Branchiostegal rays & 3 & 5 \\
\hline Dorsal fin rays & $\mathrm{I} / 12$ & XVIII/11- XVII/10 \\
\hline Anal fin rays & $\mathrm{I} / 5$ & $\mathrm{VII/9}$ \\
\hline Pelvic fin rays & $\mathrm{I} / 5$ & $15-16$ \\
\hline Pectoral fin rays & 28 & $22+13-20+11$ \\
\hline Caudal fin rays & to 5 & $12-11$ \\
\hline Lateral line scales & & \\
\hline Pre-dorsal scales & & \\
\hline
\end{tabular}

the cichlid $A$. trimaculatus not likely to be a hybrid of the ornamental group known as 'flowerhorns'.

Pterygoplichthys spp. are detrimental to the aquatic food chain. They are macrohabitat generalists and can tolerate hypoxic conditions (Ambruster, 1998) and even high levels of water pollution (Welcomme \& Vidthyanom, 2003). Hoover et al. (2004) has pointed out that these catfishes overgraze on the benthic algae and detritus, compete with native species and destroys the eggs of autochthonic species of fishes, uprooting of aquatic plants due to their behaviour of ploughing the substrate and tail lashing, cause erosion on the banks of the water bodies for creating burrows for nesting (by males) and their dorsal and pectoral spines causes mortality of piscivorous birds that prey on them. They have also been documented to migrate across the land (Nico et al., 2012). Juvenile and adult species have been recorded from shallow saline areas in South-eastern Mexico and Southern Florida, USA (Fuller et al., 1999). Field studies and experiments have shown that they can tolerate salinities up to 12 ppt (Capps et al., 2011; Kumar et al., 2018). This shows how the individual of $P$. disjunctivus survived in the brackish waters of the Sundarbans. The fishermen of the region when asked reported of never coming across this fish and thought it to be a kind of gobioid fish.

There is very scarce scientific literature on the group of fishes called 'Flowerhorns' and their introduction into nature remains very poorly documented. It is interesting to note that during the 90 s these fish were developed in Malaysia and though the true identity of the parental species is not known, a range of new world cichlids was used by breeders to create these hybrids (Lutz, 2004). Before this, A. trimaculatus or at least a hybrid of this species has been recorded from Chennai, Tamil Nadu (Knight \& Devi, 2009). Making this the second record for the species in India. The two individuals of $A$. trimaculatus were collected by the first author from a wet market in Southern West Bengal. When asked what the locals call this fish, the fishmonger said that they are known as 'colouring tilapia' and are occasionally brought by fishers for sale along and sold with Oreochromis mossambicus (Peters, 1852) and Oreochromis niloticus (Linnaeus, 1758) spp. these fish are mouthbrooders and both parents fiercely guard the eggs and tend to the fry after they have hatched (Bomford \& Glover, 2004). It is a piscivore fish that predates on smaller fish and grows in over $25 \mathrm{~cm}$. This fish has the potential to be a destructive invasive species based on reports from other regions of South-East Asia (Nico et al., 2007; Hedianto et al., 2014).

Both species of fishes show some similarity in biology and behaviour to that of an invasive species. Both are highly adaptable to a varied range of water quality, both the species show parental care to ensure better survival of their young and both the species lack predators in In- 
dian freshwater ecosystems. Pterygoplichthys disjunctivus has already been established as an invasive species across many states of India (Singh, 2014; Bijukumar et al., 2015). While smaller individuals have been recorded from the freshwater habitats in and around Sundarbans and Southern West Bengal, India throughout the year, it is not known if Pterygoplichthys disjunctivus spawn in the protected brackish waters of the Indian Sundarbans. During the rainy season, there is substantial flooding in these brackish water zones which results in low salinity levels and that may facilitate in the dispersion of these armoured catfishes. Their tolerance to low levels of salinity is one of the main reasons possibly explaining their success as an invasive species (Kumar et al., 2018). A. trimaculatus is yet to be established as an invasive species. Though there is more than one way for the introduction of exotic and or invasive species in an environment, aquarium releases are significant (Lowe et al., 2000). Upon questioning, it was found that nearby to the wet market are ponds that are used for the aquaculture of aquarium fish species and flowerhorns among other cichlids are reared in those farms. In Sundarbans, some many hotels and restaurants that have aquariums that serve the purpose of decoration and since an adult Pterygoplichthys sp. is rather unpleasing to lot at, it is possible that this individual was released to the nearby river and the fish found its way to the point where it was captured. Most traders and live fish shop owners refuse to take Pterygoplichthys spp. that has grown too big for they don't sell and would encourage fish keepers to release them in natural water bodies (P. Chakraborty, unpublished information). From the brackish zones of West Bengal, Etroplus suratensis a cichlid native to southern India and unknown to the region was recorded recently by the fifth author (Fig. 4) the effect of this species on native fauna of the region is not known. There are reports of E. suratensis being reared along with Scatophagus argus (Hamilton, 1822) at Kakdwip in the Hooghly estuarine zone, West Bengal (Ghosh \& Maity, 2018). No such fisheries are known to exist in the Sundarbans. Many freshwater rivers in India consist of fishes that are habitat specialists along with endangered species. Recording invasive species from such areas is urgent and should be followed by conservation action and management (Raghavan et al., 2008).

Local eradication of these invasive species will prove ineffective and expensive if the expanse of their ranges is not known. Both the fish has the potential to be used for fish meal, cattle feed and crab bait as they are rich in proteins and A. trimaculatus can even be consumed by hu-

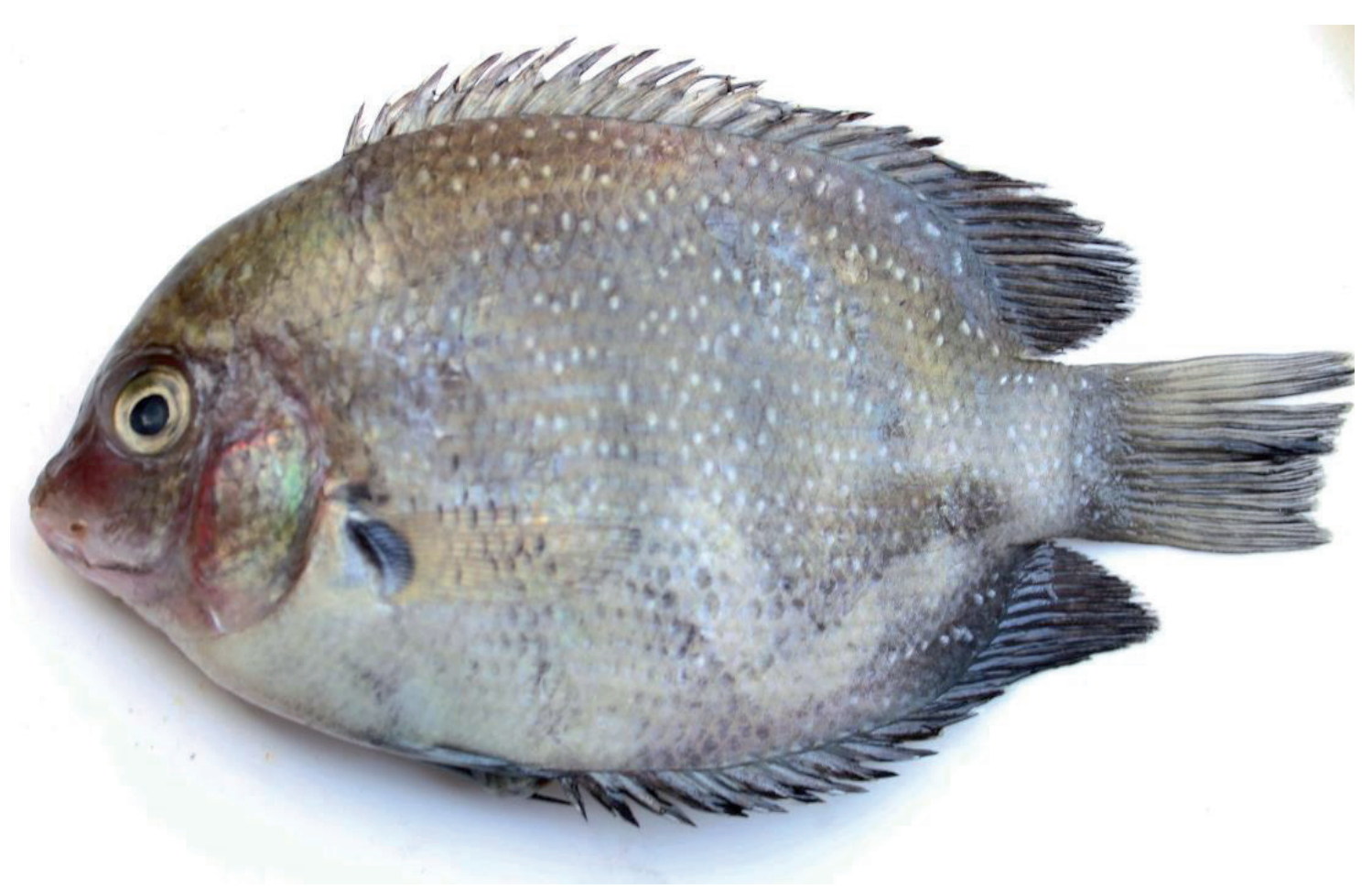

Figure 4. Etroplus suratensis (Bloch, 1790) photographed by the fifth author from a wet market in Kolkata 
mans (CEC, 2009). Cagauan (2007) suggested handcrafting dry skin as another potential use for Pterygoplichthys spp. exploiting these fishes can be tried in India. Controlling the spread of invasive species is not an easy task, but the best method to prevent introduction is through policymaking, awareness and education. It is essential to educate the buyers, sellers and the public at large. For regions like the Sundarbans, awareness materials should be developed in local languages that explain the ecological implication of the invasive species. There is a need for nationally coordinated on-the-ground management actions. Unless strict action is taken to monitor the aquarium fish trade and the accidental release of exotic fish in Indian waters, invasive fish can wipe out our native freshwater fishes.

\section{Conclusion}

It is vital to properly identify an invasive species to develop species-specific management actions. This study identifies three exotic fishes; one confirmed invasive species and two potentially invasive species $P$. disjunctivus from the brackish waters of Sundarban Tiger Reserve, West Bengal, A. trimaculatus, a cichlid native to Central America, from Indian waters and E. suratensis a cichlid native to the southern parts of India However, due to the well-recognized variability in cichlids, further genetic analysis is required to confirm their identification. $P$. disjunctivus is an invasive species and potential to establish populations in the freshwater zones of the Sundarbans using the brackish waterways as a means of dispersal. Further studies are required to find out if Pterygoplichthys is breeding the brackish waters. Although there is no evidence yet regarding the negative impact of $A$. trimaculatus ecologically. Thorough monitoring should be carried out to determine the distribution and future spread of both species in India.

\section{Acknowledgement}

The authors would like to thank Dr Erach Bharucha, Director, Bharati Vidyapeeth Institute of Environment Education $\&$ Research (BVIEER) for providing the facilities.

\section{References}

Armbruster J.W., 1998, Modifications of the digestive tract for holding air in loricariid and scoloplacid catfishes. Copeia 3: 663-675.

Ambruster J.W., 2001, Loricariid Home Page. (http://www. auburn.edu/academic/sciencemath/resarea/loricarrid/ fishkey/lorhome/main.html), [on-line version dated February 2, 2010].
Bijukumar A., Smrithy R., Sureshkumar U. \& George S., 2015, Invasion of South American suckermouth armoured catfishes Pterygoplichthys spp. (Loricariidae) in Kerala, India - a case study. Journal of Threatened Taxa 7(3): 6987-6995.

Bomford M. \& Glover J., 2004, Risk assessment model for import and keeping of exotic freshwater and estuarine finfish. Bureau of Rural Sciences, Canberra, Australia, $125 \mathrm{pp}$.

Cagauan A.G., 2007, Exotic aquatic species introduction in the Philippines for aquaculture - A threat to biodiversity or a boom to the economy? J. Environ. Sci. Manage. 10: 48-62.

Capps K.A., Nico L.G., Mendoza-Carranza M., Arevalo-Frias W., Ropicki A.J., Hellpern S.A. \& RodilesHernandez R., 2011, Salinity tolerance of non-native suckermouth armoured catfish (Loricariidae: Pterygoplichthys) in south-eastern Mexico: Implications for invasion and dispersal. Aquat. Conserv. 21: 528-540.

CEC (Commission for Environmental Cooperation), 2009, Trinational Risk Assessment Guidelines for Aquatic Alien Invasive Species: Test Cases for the Snakeheads (Channidae) and Armored Catfishes (Loricariidae) in North American Inland Waters. CEC Publications, Montreal, Canada.

Courtenay W.R., 1997, Tilapias as non-indigenous species in the Americas: environmental, regulatory, and legal issues, [in:] B.A. Costa-Pierce \& J.E. Rakocy (eds.), Tilapia Aquaculture in the Americas Vol. 1. World Aquaculture Society, Baton Rouge, LA: 18-33.

Froese R. \& Pauly D. (eds.), 2019, FishBase. World Wide Web electronic publication. (www.fishbase.org, version (02/2019)).

Fuller P.L., Nico L.G. \& Williams J.D., 1999, Nonindigenous fishes introduced into inland waters of the United States. Am. Fish. Soc. Spec. Pub. 27: 1-622.

Ghosh S. \& Maity T., 2018, Rearing of Scatophagus argus and Etroplus suratensis in coastal West Bengal, India. Aquaculture 22(3): 3-6.

Gozlan R.E., Britton J.R., Cowx I. \& Copp G.H., 2010, Current knowledge on non-native freshwater fish introductions. Journal of Fish Biology 76(4): 751-786.

Hedianto D.A., Purnomo K., Kartamihardja E.S. \& Warsa A., 2014, Parameter populasi ikan lohan (Cichlasoma trimaculatum, Günther 1867) di Waduk Sempor, Jawa Tengah. J. Lit. Perikan. Ind. 20(2): 81-88.

Hoover J.J., Killgore K.J. \& Cofrancesco A.F., 2004, Suckermouth catfishes: Threats to aquatic ecosystems of the United States. Aquatic Nuisance Species Research Bulletin 4: 1-8.

Hossain M.Y., Rahman M.M., Ahmed Z.F., Ohtomi J. \& Islam A.B.M.S., 2008, First record of the South American sailfin catfish Pterygoplichthys multiradiatus in Bangladesh. Journal of Applied Ichthyology 24: 718-720. 
Knight J.D.M. \& Devi K.R., 2009, On a record of Amphilophus trimaculatum (Günther) (Teleostei: Perciformes: Cichlidae) in the natural waters of Tamil Nadu, India. Journal of the Bombay Natural History Society 106(3): 347-348.

Krishnakumar K., Raghavan R., Prasad G., Bijukumar A., Sekharan M., Periera B. \& Ali A., 2009, When pets become pests - exotic aquarium fishes and biological invasions in Kerala, India. Current Science 97: 474-476.

Kumar A.B., Schofield P.J., Raj S. \& Satheesh S., 2018, Salinity tolerance of non-native suckermouth armoured catfish (Loricariidae: Pterygoplichthys sp.) from Kerala, India. Management 9(1): 49-57.

Leidy R.A. \& Moyle P.B., 1998, Conservation status of the world's fresh water fish fauna: an overview, [in:] P.L. Fielder, P.M. Karieva (eds.), Conservation Biology: For Coming Decade, 2nd edition. Chapman and Hall, New York: 187-227.

Liang S.H., Wu H.P. \& Shieh B.S., 2005, Size, structure, reproductive phenology and sex ratio of an exotic Armoured Catfish (Liposacrus multiradiatus) in Kaoping River of Southern Taiwan. Zoological Studies 44(2): 252-259.

Lowe S., Browne M., Boudjelas S. \& De Poorter M., 2000, 100 of the World's Worst Invasive Alien Species A selection from the Global Invasive Species Database. The Invasive Species Specialist Group (ISSG) a specialist group of the Species Survival Commission (SSC) of the World Conservation Union (IUCN), Auckland, New Zealand, 12 pp. (www.issg.org/booklet.pdf).

Lutz C.G., 2004, When hybrids attack. Aquaculture Magazine 30 (6): 1-2.

Nico L.G., Loftus W.F. \& Reid J.P., 2009, Interactions between armored suckermouth catfish (Loricariidae: Pterygoplichthys) and native Florida manatee (Trichechus manatus latirostris) in artesian springs. Aquatic Invasions 4: 511-519.

Nico L.G., Beamish W.H. \& Musikasinthorn P., 2007, Discovery of the invasive Mayan Cichlid fish "Cichlasoma" urophthalmus (Günther 1862) in Thailand, with comments on other introductions and potential impacts. Aquatic Invasions 2(3): 197-214.

Nico L.G., Schofield P.J. \& Neilson M.E., 2019, Oreochromis niloticus (Linnaeus, 1758): U.S. Geologi- cal Survey, Nonindigenous Aquatic Species Database, Gainesville, FL. (https://nas.er.usgs.gov/Queries/FactSheet.aspx?speciesID $=468$, Revision Date: 6/17/2019, Peer Review Date: 4/1/2016), [Accessed: 10/19/2019].

Nico L.G., Butt P.L., Johnson G.R., Jelks H.L., Kail M. \& Walsh S.J., 2012, Discovery of the South American Suckermouth Armoured Catfish (Loricariidae, Pterygoplichthys spp.) in the Santa Fe River drainage, Suwannee River basin, USA. Bioinvasion Records 1: 179-200. (http://dx.doi.org/10.3391/bir.2012.1.3.04).

Page L.M. \& R.H. Robins, 2006, Identification of sailfin catfishes (Teleostei: Loricariidae) in Southeastern Asia. Raffles Bull. Zool. 54(2): 455-457.

Pullan S. \& Smith P.J., 1987, Identification of hybrids between koi (Cyprinus carpio) and goldfish (Carassius auratus). New Zealand Journal of Marine and Freshwater Research 21(1): 41-46.

Raghavan R., Dahanukar N., Tlusty M.F., Rhyne A.L., Krishna Kumar K., Molur S. \& Rosser A.M., 2013, Uncovering an obscure trade: Threatened freshwater fishes and the aquarium pet markets. Biological Conservation 164:158-169. (http://dx.doi.org/10.1016/j.biocon.2013.04.019).

Raghavan R., Prasad G., Anvar-Ali P.H. \& Pereira B., 2008, Exotic fish species in a global biodiversity hotspot: Observations from River Chalakudy, part of Western Ghats, Kerala, India. Biological Invasions 10: 37-40.

Rahel F.J., 2002, Homogenization of freshwater faunas. Annual Review of Ecology and Systematics 33(1): 291-315.

Říčan O., Piálek L., Dragová K. \& Novák J., 2016, Diversity and evolution of the Middle American cichlid fishes (Teleostei: Cichlidae) with revised classification. Vertebrate Zoology 66(1): 1-102.

Singh A.K., 2014, Emerging alien species in Indian aquaculture: prospects and threats. Journal of Aquatic Biology \& Fisheries 2: 32-41.

Welcomme R. \& Vidthayanom C., 2003, The impacts of introductions and stocking of exotic species in the Mekong Basin and policies for their control. MRC Technical Paper No. 9, Mekong River Commission, Phnom Penh, 38 pp. 